\title{
SSU rDNA analysis of Kudoa rosenbuschi (Myxosporea) from the Argentinean hake Merluccius hubbsi
}

\author{
Elvira Abollo $^{1,2, *}$, Beatriz Novoa ${ }^{1}$, Antonio Figueras ${ }^{1}$ \\ ${ }^{1}$ Instituto de Investigaciones Marinas (CSIC), Eduardo Cabello 6, 36208 Vigo, Spain \\ ${ }^{2}$ Present address: Centro de Investigacions Mariñas, Conselleria de Pesca e Asuntos Maritimos, Xunta de Galicia, \\ Apartado 13, 36620 Vilanova de Arousa, Spain
}

\begin{abstract}
The cloning and sequencing of the small subunit (SSU) ribosomal DNA gene from Kudoa rosenbuschi (myxosporean species associated with post-mortem myoliquefaction process in the Argentinean hake Merluccius hubbsi) is reported. The SSU rDNA was found to contain $1740 \mathrm{bp}$ with a single polymorphic site with either a $\mathrm{C}$ or $\mathrm{T}$ at position 221 . The sequence data obtained in this study and those known sequences of Kudoa species deposited in the GenBank were all analyzed to construct a phylogenetic tree. Nucleotide sequences showed the highest degree of identity with $K$. funduli, followed by $K$. miniauriculata, $K$. clupeidae and $K$. dianae. Phylogenetic analysis placed $K$. rosenbuschi in the same branch of $K$. clupeidae and $K$. funduli, and showed it to be closely related to K. dianae, K. paniformis and K. miniauriculata.
\end{abstract}

KEY WORDS: Kudoa $\cdot$ Myxozoa $\cdot$ SSU rDNA $\cdot$ Hake $\cdot$ Merluccius hubbsi

\section{INTRODUCTION}

The Argentinean hake Merluccius hubbsi is distributed in a wide area of the south-western Atlantic Ocean inhabiting Brazilian, Uruguayan and Argentinean waters, and is a target species for Argentinean and Uruguayan fisheries (Nión 1985, Otero \& Verazay 1988, FAO 1998). The hake musculature is infected by pseudocysts of Kudoa rosenbuschi which are originally microscopic and white (Sardella 1988). The pseudocysts become macroscopically visible and have a characteristic dark color caused by the accumulation of breakdown products. Sardella (1988) demonstrated the existence of proteolysis in Argentinean hake skeletal muscle around white and black pseudocysts. Martone et al. (1999) showed that pseudocysts of $K$. rosenbuschi contained an abundant cysteine protease (Mr $147.2 \mathrm{kDa}$ ), which has a great ability to degrade in vitro constituents of whole myofibrils of the hake skeletal muscle. However, M. hubbsi infected by $K$. rosenbuschi do not show an intense jellied process (as a result of myofibril degradation) because the formation of black pseudocysts with thick walls prevents the secretion and posterior diffusion of proteases (Martone et al. 1999). Nevertheless, higher proteolysis processes were observed around microscopic pseudocysts, which do not have conjunctive walls.

With the increased importance of myxozoan diseases, the use of molecular biological methods has made it possible to develop highly sensitive and specific diagnostic tests and to expand taxonomic classification by phylogenetic analysis (Kent et al. 2001). Molecular analysis based on sequences of the small subunit (SSU) rDNA has been applied to the study of Kudoa species, showing that morphological characters must be used in conjunction with a molecular approach in order to characterize the members of this genus (Hervio et al. 1997, Kent et al. 2001, Dyková et al. 2002, Whipps et al. 2003a,b).

In this work we provide the nucleotide sequence of SSU rDNA for Kudoa rosenbuschi in order to establish 
the degree of differences at molecular level and to increase the understanding of the phylogeny of the multivalvulid myxosporeans.

\section{MATERIALS AND METHODS}

Sampling and microscopic identification. Samples of infected Argentinean hakes Merluccius hubbsi, were provided by a local seafood industry. The hakes from the southwest Atlantic Ocean (FAO zone 41) were caught by commercial ships, filleted and frozen. In the laboratory, fillets were examined macroscopically and individual black pseudocysts were extracted under a dissecting microscope, cleaned to remove host tissue, and washed with $20 \mathrm{mM}$ phosphate buffer $\mathrm{pH}$ 7.5. Myxospores were collected directly from the pseudocysts and preserved in $70 \%$ ethanol. Wetmount preparations were also used for parasite identification.

DNA extraction. The spores preserved in $70 \%$ ethanol were lysed in $5 \mathrm{ml}$ Tris $10 \mathrm{mM} \mathrm{pH} \mathrm{7.8,} \mathrm{EDTA}$ $5 \mathrm{mM}, \mathrm{NaCl}_{1}$ SDS $0.5 \%$ with proteinase $\mathrm{K}(20 \mathrm{mg}$ $\mathrm{ml}^{-1}$ ) overnight at $37^{\circ} \mathrm{C}$. Subsequently, the DNA was purified with 2 phenol:chloroform:isoamil alcohol extractions, followed by 1 chloroform:isoamil alcohol extraction. DNA was precipitated with ethanol and sodium acetate overnight $-20^{\circ} \mathrm{C}$. The precipitated pellet was resuspended in $50 \mu \mathrm{l}$ of Tris-EDTA (TE) buffer.

DNA amplification, cloning and sequencing. Two conserved primers $\mathrm{U} 1$ and $\mathrm{U} 2$ were used in PCR to amplify the small subunit (18S) ribosomal DNA gene (Table 1). PCR reactions were performed in total volume of $25 \mu \mathrm{l}$ containing $1 \mu \mathrm{l} 10 \mathrm{mM}$ dNTP mix, $0.125 \mu \mathrm{l} \mathrm{Taq}$ polymerase, $2.5 \mu \mathrm{l}$ Taq $10 \times$ buffer, $1.25 \mu \mathrm{l} \mathrm{MgCl}{ }_{2} 25 \mathrm{mM}, 1.25 \mu \mathrm{l}$ of each primer $(100 \mu \mathrm{M})$ and $1 \mu \mathrm{l}$ of cDNA. The cycling protocol was $95^{\circ} \mathrm{C}$ for $3 \mathrm{~min}, 30$ cycles of $94^{\circ} \mathrm{C}$ for $1 \mathrm{~min}$, $53^{\circ} \mathrm{C}$ for $1 \mathrm{~min}$ and $72^{\circ} \mathrm{C}$ for $2 \mathrm{~min}$, followed by $72^{\circ} \mathrm{C}$ for $10 \mathrm{~min}$. PCR products were separated on a $1 \%$ agarose gel stained with ethidium bromide and analyzed using a UV image analysis system.

Fresh PCR products were ligated into T/A cloning vector pGEM-T Easy (Promega) at $4{ }^{\circ} \mathrm{C}$ overnight and transformed into E. coli One Shot ${ }^{\circledR}$ Top 10F' Chemically Competent (Invitrogen). Eight randomly selected clones were initially sequenced using the universal sequencing primers M13F (5' GTA AAA CGA CGG CCA G 3') and M13R (5' CAG GAA ACA GCT ATG AC 3') present in the vector. Based on the obtained sequences, specific primers were synthesized using Primer-3 program (Table 1) and employed to obtain the entire sequence. DNA sequencing was performed by the dideoxy-chain termination method using a BigDye terminator Cycle Sequencing Ready Reaction Kit (Applied Biosystems) and an automated DNA sequencer ABI PRISM ${ }^{\mathrm{TM}} 377$ (Applied Biosystems). Each PCR product was sequenced twice with the same primer.

Sequence analysis. Basic Local Alignment Search Tool (BLAST) analysis from the National Center for Biotechnology Information (Bethesda, MD, USA) was used to search the GenBank for homologous nucleotide sequences and to determine whether the sequences were of host or parasite origin. Multiple sequence alignments were generated using Clustal X. A phylogenetic tree based on the SSU rRNA gene sequences was performed using the Neighbor-Joining (NJ) algorithm within MEGA version 2.1.

The GenBank accession numbers of the SSU rRNA gene sequences used are as follows: Kudoa quadricornis (AY078428), K. amamiensis from Australia (AY152748), K. amamiensis from Japan (AF034638), $K$. crumena (AF378347), K. ciliatae (AF378348), K. dianae (AF414692), K. miniauriculata (AF034639), $K$. paniformis (AF034640), K. permulticapsula (AY078429), K. minithyrsites (AY152749), K. clupeidae (AY197771), K. ovivora (AY152750), K. funduli (AY312279), K. thyrsites from Salmo salar (AF031412), K. thyrsites from Alurorhynchus flavidus (AF031413), K. thyrsites from Coryphaena hippurus (AY152747), K. thyrsites from Thyrsites atun (AY078430), Pentacapsula neurophila (AY172511) and Zschokkella mugilis (AF411336).

Table 1. Kudoa rosenbuschi. Positions and sequences of specific primers used for PCR amplification and sequencing

\begin{tabular}{|lcc|}
\hline $\begin{array}{c}\text { Primer } \\
\text { (direction) }\end{array}$ & \multicolumn{1}{c|}{ Sequence $\left(5^{\prime}\right.$ to $\left.3^{\prime}\right)$} & Position \\
\hline $\begin{array}{l}\text { U1 } \\
\text { (forward) }\end{array}$ & AAC CTG GTT GAT CCT GCC AGT & $1-21$ \\
$\begin{array}{l}\text { U2 } \\
\text { (reverse) }\end{array}$ & TGA TCC TTC TGC AGG TTC ACC TAC & $1717-1740$ \\
$\begin{array}{l}\text { SSU1 } \\
\text { (forward) }\end{array}$ & ACC AAG GTT GTG ACG GGT AA & $323-342$ \\
$\begin{array}{l}\text { SSU2 } \\
\text { (forward) }\end{array}$ & CGA ATG TTA TAG CAT GGA ACG A & $766-787$ \\
$\begin{array}{l}\text { SSU3 } \\
\text { (reverse) }\end{array}$ & AGG CTC AGT CCA AAG CAA GA & $1486-1505$ \\
$\begin{array}{l}\text { SSU4 } \\
\text { (forward) }\end{array}$ & TCG CTA CTA CCG ACT GGA TG & $1597-1616$ \\
\hline
\end{tabular}




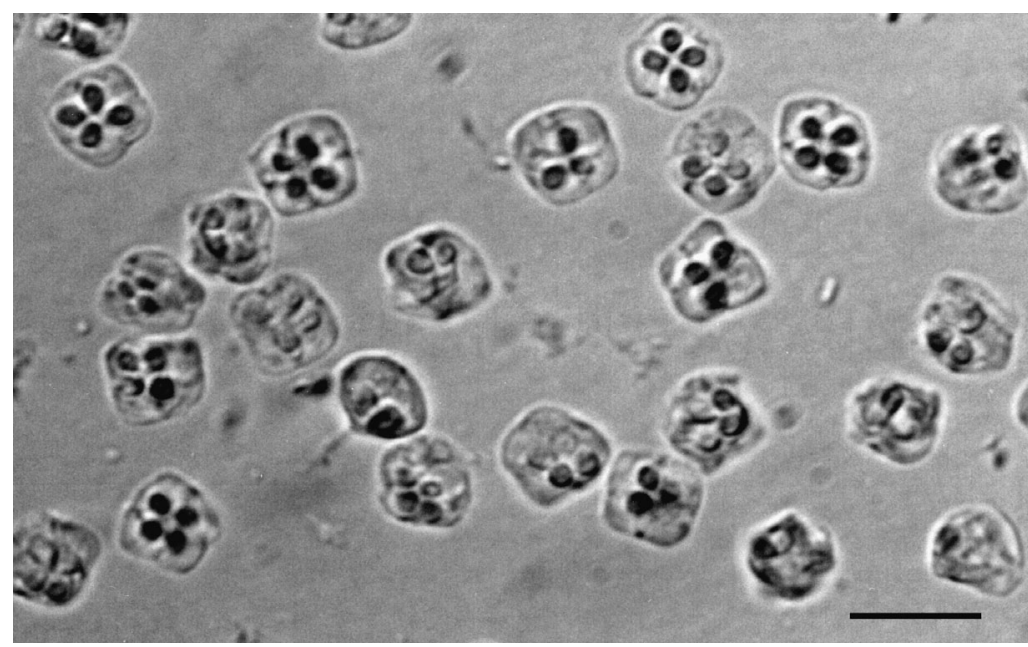

Fig. 1. Kudoa rosenbuschi from Merluccius hubbsi. Fresh smear of mature spores from pseudocysts infecting the muscle of the Argentinean hake M. hubbsi. Scale bar $=10 \mu \mathrm{m}$

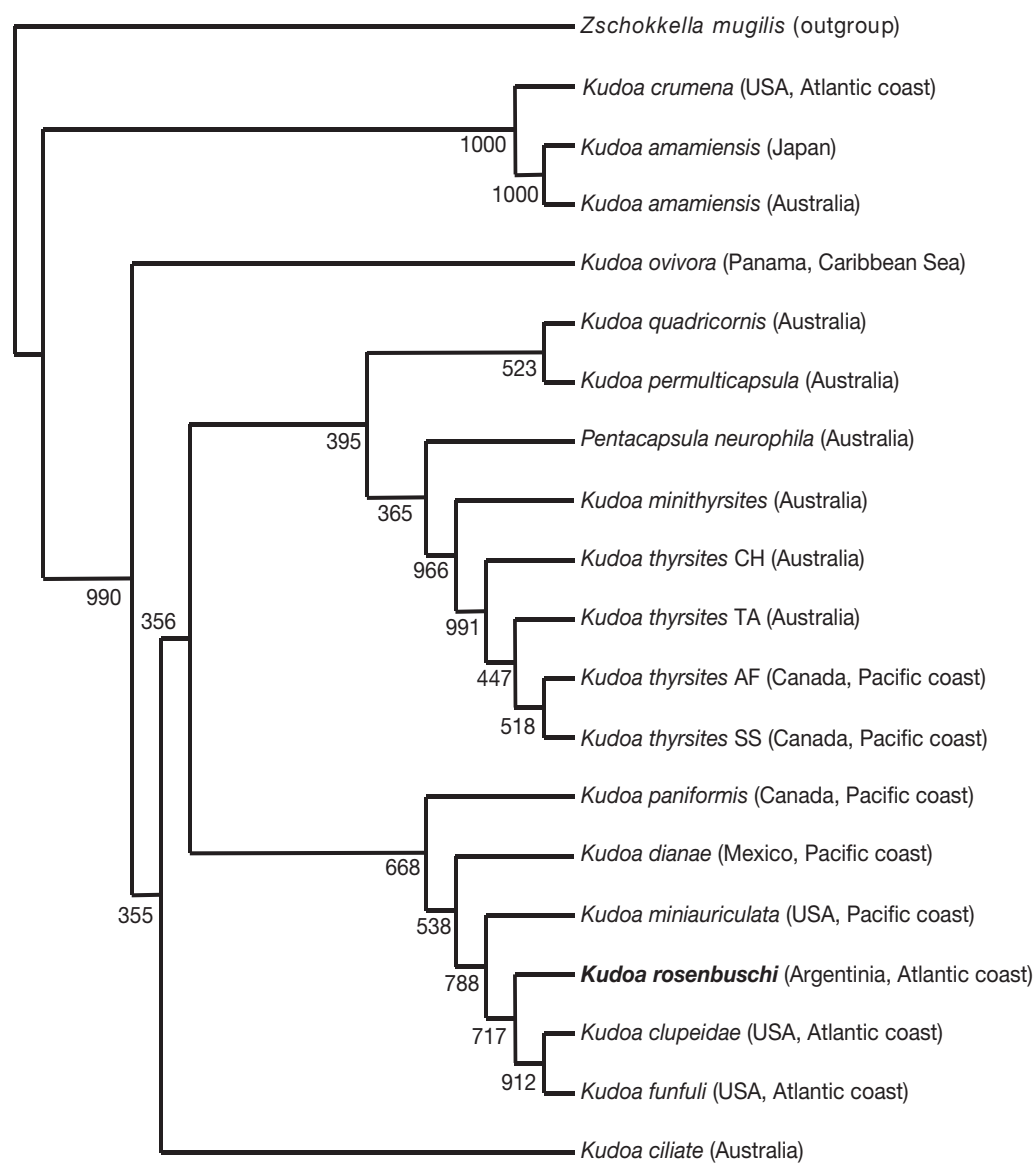

Fig. 2. Phylogenetic tree showing the taxonomic position of Kudoa rosenbuschi (in bold) in relation to compared myxosporeans. Numbers at branch nodes indicate bootstrap confidence values. $K$. thyrsites AF: $K$. thyrsites from Alurorhynchus flavidus; K. thyrsites SS: K. thyrsites from Salmo salar; K. thyrsites TA: $K$. thyrsites from Thyrsites atun; $K$. thyrsites $\mathrm{CH}$ : $K$. thyrsites from Coryphaena hippurus

\section{RESULTS}

Black pseudocysts (length 2.1 to $10.5 \mathrm{~mm}$, diameter 0.5 to $1.2 \mathrm{~mm}$ ) containing Kudoa spores were found infecting the musculature of Argentinean hake. The morphology of myxospores as seen in wet mount preparations was consistent with those of Kudoa rosenbuschi found in the Merluccius hubbsi muscle (Fig. 1).

Conserved SSU rDNA primers U1 and U2 yielded a single 1740 bp amplicon (including regions corresponding to forward and reverse primers) from every sample examined. GenBank Blast search confirmed that it belongs to 18S rDNA and bears the closest similarity to other Kudoa species. The sequences generated were edited, assembled, and aligned to obtain the 18S rDNA sequence of $K$. rosenbuschi and finally registered in GenBank with the accession no. AY623795. A single polymorphic site with either a $\mathrm{C}$ or $\mathrm{T}$ at position 221 was detected. Both variants of the sequence were isolated from a single fillet. In almost all of the clones ( 2 of 8 ) the sequence showed $\mathrm{T}$ nucleotide at this position.

The SSU rRNA sequence of Kudoa rosenbuschi was aligned with the first 19 BLAST-defined species and a phylogenetic tree was generated using NJ algorithm (Fig. 2). The bootstrap values are based upon 1000 replicates, and the ssu rRNA sequence of Zschokkella mugilis was used as the outgroup. The phylogenetic dendogram defined the taxonomic position of $K$. rosenbuschi in a branch with $K$. clupeidae and $K$. funduli and closely related to $K$. dianae, $K$. paniformis, and $K$. miniauriculata with bootstrap values of $66.8 \%$. Identity values between 18S rDNA gene sequence of $K$. rosenbuschi and those from compared organisms ranged from 84.98 to $97.16 \%$ (Table 2). The highest nucleotide identity values were obtained with $K$. funduli at $97.16 \%$ sequence identity, followed by $K$. miniauriculata $(97.07 \%)$, $K$. clupeidae $(96.99 \%)$ and $K$. dianae $(96.57 \%)$. The lowest nucleotide identity values were observed with $K$. amamiensis and $K$. crumena, indicating a more distant evolutionary relationship. 
Table 2. Percentage of nucleotide identity of Kudoa rosenbuschi SSU rDNA compared with SSU rDNA sequences of other myxosporeans. Species names in parentheses indicate host species. Zschokkella mugilis is an outgroup

\begin{tabular}{|lc|}
\hline Species & $\begin{array}{c}\text { Nucleotide } \\
\text { identity (\%) }\end{array}$ \\
\hline Kudoa funduli & 97.16 \\
Kudoa miniauriculata & 97.07 \\
Kudoa clupeidae & 96.99 \\
Kudoa dianae & 96.57 \\
Pentacapsula neurophila & 96.02 \\
Kudoa quadricornis & 95.92 \\
Kudoa paniformis & 95.87 \\
Kudoa thyrsites (Alurorhynchus flavidus) & 95.48 \\
Kudoa thyrsites (Salmo salar) & 95.42 \\
Kudoa thyrsites (Coryphaena hippurus) & 95.15 \\
Kudoa permulticapsula & 94.85 \\
Kudoa ovivora & 94.80 \\
Kudoa thyrsites (Thyrsites atun) & 94.28 \\
Kudoa minithyrsites & 93.99 \\
Kudoa ciliatae & 91.38 \\
Kudoa amamiensis (Australia) & 90.60 \\
Kudoa crumena & 90.50 \\
Kudoa amamiensis (Japan) & 90.23 \\
Zschokkella mugilis & 84.98 \\
\hline
\end{tabular}

\section{DISCUSSION}

Species of the genus Kudoa (Myxozoa: Myxosporea) are characterized as primarily histozoic parasites of the skeletal musculature of marine and estuarine fishes worldwide. The list of species belonging to this genus was expanded to 52, with 5 new species described recently (Moran et al. 1999, Dyková et al. 2002, Whipps et al. 2003a,b, Cho \& Kim 2003). Certain species are of economic concern to aquaculture and commercial marine fisheries because they either cause unsightly pseudocysts in the muscle or they produce postmortem myoliquefactive autolysis, also known as 'soft flesh', when the fish is stored at high temperatures (Moran et al. 1999). The consequences of K. rosenbuschi infections for the seafood processing plants are serious because the infected fish show no signs of disease. It is only after death, in filleted and frozen fish, that the black pseudocysts are visible and the host tissue becomes degraded. K. rosenbuschi is considered to be resticted to a specific host species and has been reported previously from Argentinean and Uruguayan waters infecting the musculature of Merluccius hubbsi with a prevalence higher than 10\% (Sardella 1988, Sardella \& Timi 1996).

Traditionally, the taxonomic classification of the myxozoans has been based on spore morphology. Molnár (1994) suggested that other features, such as geographic origin, host species or tissue specificity, could be useful characters for specific assignment. Recently, studies based on the comparison of 18S rDNA among myxozoans have confirmed the importance of the above phenotypic features (Kent et al. 2001). Andree et al. (1999) and Eszterbauer (2004) found that species of the genus Myxobolus were related primarly by their tissue specificity. Our phylogenetic analysis revealed a dendogram which was consistent with what is known from previous studies (Whipps et al. 2003b). Two independent branches were formed by extra-muscular parasites, Kudoa ciliatae parasitizing the intestinal wall of Sillago ciliata (Kent et al. 2001) and K. ovivora parasitizing the ovaries of Thalassoma bifasciatum (Whipps et al. 2003b). Nevertheless, $K$. dianae, which infect the oesophagus of bullseye puffer, was clustered with other muscular species of Kudoa. Because most of the Kudoa sequences used in the phylogenetic tree belonged to muscular species, the tissue specificity could not be evaluated in the phylogenetic analysis. In order to assess the importance of the tissue specificity on phylogenetic relationships, a higher number of Kudoa species with different tissue tropism is desirable. Based on the analysis of 5 Kudoa species, Hervio et al. (1997) suggested that members of this genus are clustered to a greater extend by their geographic origin more than by the spore morphology. $K$. rosenbuschi is clustered with $K$. clupeidae and $K$. funduli, which are species collected from different host species of the Atlantic coast, but it is also closely related with Kudoa species collected from fishes of the Pacific coast. Nevertheless, Dyková et al. (2002) suggested that it might be necessary to use other molecular approaches, due to the low bootstrap values of the phylogenetic tree.

The Kudoa spores are morphologically characterized by having 4 valves and 1 polar capsule by valve (Meglitsch 1947). It is noticeable that Pentacapsula neurophila (a species with 5 polar capsules) is included within a clade comprised of Kudoa species, although this arrangement was weak as reflected by the low bootstrap support obtained at the node (36.5\%). Recently, Whipps et al. (2003a) described a new species, $K$. permulticapsula, which has 13 polar capsules. According to these authors, this morphological feature could make it possible to assign this species to a new genus. However, phylogenetic analysis of the ssu rDNA sequences assigned $K$. permulticapsula to a clade comprised of Kudoa species, a monophyletic group (Hervio et al. 1997; Kent et al. 2001). Following these results, Whipps et al. (2003a) amended the morphological diagnosis of Kudoa to place $K$. permulticapsula within this genus. The new taxonomic diagnosis proposed by Whipps et al. (2003a) characterized the Kudoa species as having spores with 4 or 13 polar capsules and an equal number of valves. This taxonomic statement would mean that some genera, such as Pentacapsula or Hexacap- 
sula, could be eliminated and placed in the genus Kudoa. Nevertheless, further molecular analysis of Kudoa species is clearly required to draw a complete phylogenetic picture.

Acknowledgements. This research was supported by a Marie Curie Fellowship of the European Community Fifth Framework Programme under contract no. QLK5-CT-200251499.

\section{LITERATURE CITED}

Andree KB, Székely C, Molnár K, Gresoviac SJ, Hedrick RP (1999) Relationships among members of the genus Myxobolus (Myxozoa: Bilvalvidae) based on small subunit ribosomal DNA sequences. J Parasitol 85:68-74

Cho JB, Kim KH (2003) Light- and electron-microscope description of Kudoa paralichthys n.sp. (Myxozoa, Myxosporea) from the brain of cultured olive flounder Paralichthys olivaceus in Korea. Dis Aquat Org 55:59-63

Dyková I, Fajer Avila EJ, Fiala I (2002) Kudoa dianae sp.n. (Myxosporea: Multivalvulida), a new parasite of bullseye puffer, Sphoeroides annulatus (Tetraodontiformes: Tetraodontidae). Folia Parasitol 49:17-23

Eszterbauer E (2004) Genetic relationship among gill-infecting Myxobolus species (Myxosporea) of cyprinids: molecular evidence of importance of tissue-specificity. Dis Aquat Org 58:35-40

FAO (1998) Yearbook of fishery statistics 1996. Capture Production, Vol 82. FAO, Rome, p 1-694

Hervio DML, Kent ML, Khattra J, Sakanari J, Yokohama H, Devlin RH (1997) Taxonomy of Kudoa species (Myxosporea), using a small-subunit ribosomal DNA sequence. Can J Zool 75:2112-2119

Kent ML, Andree KB, Bartholomew JL, El-Matbouli M and 12 others (2001) Recent advances in our knowledge of the Myxozoa. J Eukaryot Microbiol 48:395-413

Martone CB, Spivak E, Busconi L, Folco EJE, Sánchez JJ

Editorial responsibility: Wolfgang Körting,

Hannover, Germany
(1999) A cystein protease from myxosporean degrades host myofribils in vitro. Comp Biochem Physiol B 123:267-272

Meglitsch PA (1947) Studies on Myxosporidia from the Beaufort Region: II. Observations on Kudoa clupeidae (Hhan), gen. nov. J Parasitol 33:271-277

Molnár K (1994) Comments on the host, organ and tissue-specificity of fish myxosporeans and on the types of their intrapiscine development. Parasitol Hung $27: 5-20$

Moran JDW, Whitaker DJ, Kent ML (1999) A review of the myxosporean genus Kudoa Meglitsch, 1947, and its impact on the international aquaculture industry and commercial fisheries. Aquaculture 172:163-196

Nión H (1985) Análisis de la investigación biológico pesquera en el Uruguay. Serie Investigaciones, Vol 22. Centro Interdisciplinario de Estudios sobre el Desarrollo (CIEDUR), Uruguay, p 1-162

Otero H, Verazay G (1988) El estado actual del recurso merluza común (Merluccius hubbsi) y pautas para su manejo pesquero. Publ Com Téc Mixta Frente Marítimo 4:7-24

Sardella NH (1988) Descripción de la espora y de los estadios previos del mixosporidio Kudoa rosenbuschi, parásito muscular de Merluccius hubbsi. Ciclo de vida. Parasitol al Dia 12:8-13

Sardella NH, Timi JT (1996) Parasite communities of Merluccius hubbsi from the Argentinian-Uruguayan common fishing zone. Fish Res 27:81-88

Whipps CM, Adlard RD, Bryant MS, Kent ML (2003a) Two unusual myxozoans, Kudoa quadricornis n. sp. (Multivalvulida) from the muscle of goldspotted trevally (Carangoides fulvoguttatus) and Kudoa permulticapsula n. sp. (Multivalvulida) from the muscle of Spanish mackerel (Scomberomorus commerson) from the Great Barrier Reef, Australia. J Parasitol 89:168-173

Whipps CM, Adlard RD, Bryant MS, Lester RJ, Findlay V, Kent ML (2003b) First report of three Kudoa species from eastern Australia: Kudoa thyrsites from eastern Australia: Kudoa thyrsites from mahi mahi (Coryphaena hippurus), Kudoa amamiensis and Kudoa minithyrsites n. sp. from sweeper (Pempheris ypsilychnus). J Eukaryot Microbiol 50:215-219

Submitted: June 7, 2004; Accepted: November 29, 2004 Proofs received from author(s): March 8, 2005 